\title{
Evaluation of microbiological quality of atmospheric air in a selected sewage treatment plant in Lesser Poland
}

\author{
Iwona Paśmionka $\mathbb{1}$
}

Received: 28 May 2019/Accepted: 15 January 2020/Published online: 24 January 2020

(C) The Author(s) 2020

\begin{abstract}
The adverse impact of sewage treatment plants on the environment, resulting from the emission of harmful biological agents to the atmosphere, depends mainly on the size of the facility, the quantity and composition of treated sewage as well as the technologies and equipment used. The aim of the conducted research was to determine the microbiological quality of atmospheric air at MunicipalIndustrial Sewage Treatment Plant in Oświęcim, which is one of the largest treatment plants in Lesser Poland. Bioaerosol measurements were made at four points (raw sewage inlet, aeration chamber, purified sewage outlet and $150 \mathrm{~m}$ from the treatment plant, at the background point) in the period from January to December 2018. Bioaerosol samples were collected using Microbiological Air Sampler MAS-100 by Merck. The tested atmospheric air was characterized by a qualitatively and quantitatively diverse microflora. The largest source of emission of microorganisms to the atmosphere was the mechanical part of the sewage treatment plant (raw sewage inlet) and the biological reactor. The highest number of mesophilic bacteria was observed near the biological reactor (in the summer), the least at the control point. During the research, the least $\beta$-hemolytic bacteria was isolated at
\end{abstract}

I. Paśmionka $(\bowtie)$

Department of Microbiology and Biomonitoring,

University of Agriculture in Kraków, Mickiewicza Ave

21, 31-120 Kraków, Poland

e-mail: iwona.pasmionka@urk.edu.pl the purified sewage outlet-on average $3 \mathrm{CFU} \mathrm{m} \mathrm{m}^{-3}$, the highest at the biological reactor $16 \mathrm{CFU} \mathrm{\textrm {m } ^ { - 3 }}$. Most of $\alpha$-hemolytic bacteria was observed near the raw sewage inlet and was not found at the control point. Actinomycetes also occurred in a small amount (0-40 $\mathrm{CFU} \mathrm{m} \mathrm{m}^{-3}$ ). A high concentration of mildew fungi occurred in summer when the air temperature was highest, the smallest quantities of these microorganisms were found in January and February.

Keywords Bioaerosol - Atmospheric air · Microbial contamination $\cdot$ Sewage treatment plant

\section{Introduction}

Microbiological contaminants occurring in the atmospheric air come from various sources, including, among others, municipal facilities, e.g., sewage treatment plants, landfills and composting. The side effect of these objects is the formation of biological aerosols containing numerous microorganisms. They pose a serious threat to human and animal health, and may also have a negative impact on the environment (Adamus-Białek et al. 2015; Michalkiewicz et al. 2011; Przybulewska and Czupryniak 2006; Vantarakis et al. 2016).

The bioaerosol formed in wastewater treatment plants includes viruses, bacteria and fungi, the form of 
which may be different, e.g., spores, conidia, parts of the mycelium, vegetative forms (Bawiec et al. 2016; Lee et al. 2016). Their survival in air compared to wastewater changes significantly, because the air does not contain nutrients and does not provide adequate physicochemical conditions (Bawiec et al. 2016; Lee et al. 2016).

Wastewater treatment plants, in addition to a positive role related to the protection of the natural environment, pose a certain risk to workers and people living nearby (Nowojewski and Mniszek 2006; Sánchez-Monedero et al. 2008). Bioaerosol, which releases into the air, carries active pathogens that can lead to serious inflammatory, infectious and allergic diseases. Exposure to biological agents in sewage treatment plant employees is most often associated with the occurrence of such diseases as alveolitis (Thorn and Kerekes 2001), rhinitis, pharyngitis, conjunctivitis and gastrointestinal infections (Ahire and Bhalerao 2017). In particular, the presence of fungi in elevated concentrations can cause a wide spectrum of diseases from simple allergies to serious infections (mycoses) (Krajewski et al. 2004). The most common complaints reported by employees of the treatment plants include malaise, coughing and breathing difficulties (Patil and Kamble 2017; Rylander 1999). The threat to health and the environment resulting from the emission of bioaerosol makes it necessary to control the microbiological contamination of air in the sewage treatment plant and in its immediate vicinity ( $\mathrm{Li}$ et al. 2013; Bauer et al. 2002; Korzeniewska 2011).

Taking into account this state of affairs, the aim of the conducted research was to characterize the microbiological quality of atmospheric air in the area of the Municipal-Industrial Sewage Treatment Plant in Oświęcim.

\section{Materials and methods}

The research was carried out at the MunicipalIndustrial Sewage Treatment Plant in Oświęcim. It is one of the largest wastewater treatment plants in Poland, located in the southern part of Lesser Poland. The sewage treatment plant receives municipal sewage from the city of Oświęcim and other towns belonging to the Oświęcim community as well as industrial sewage coming from Chemical Company
"Synthos." The incoming sewage is treated in biological processes based on the activated sludge method in the anaerobic-aerobic system. The treated wastewater is discharged to the Vistula River.

The bioaerosol assessment was carried out from January to December 2018. Air samples were collected using Microbiological Air Sampler MAS-100 by Merck at four points: raw sewage inlet (point 1), aeration chamber (point 2), purified sewage outlet (point 3) and $150 \mathrm{~m}$ from treatment plant (point 4); this point was the background. Selected research points included the basic technological stages of wastewater treatment, therefore they were considered as potential sources of microbial contamination. Additionally, for the purposes of comparing the obtained results, a measuring stand was determined in which the background level was examined. The air sampler sucked in air into a 9-cm Petri dish containing a specific solid medium intended for the isolation of selected microorganisms. The volume of air intake was 100 and $200 \mathrm{dm}^{3}$. In the case of fungi, $100 \mathrm{dm}^{3}$ of air was collected for each sample, for the remaining microorganisms, $200 \mathrm{dm}^{3}$ each. The device's inlet was always on the windward side. Air samples were taken from the height of $130 \mathrm{~cm}$ above ground level that is from the human breathing zone. Each air measurement for the tested groups of microorganisms was made in three replications. The following microbiological media were used for culturing microorganisms:

1. Tryptic soy agar (TSA LAB-AGARTM, Biocorp, Poland) with 5\% addition of sheep blood, in order to determine the total number of bacteria, $\alpha$ - and $\beta$-hemolytic bacteria.

2. Gauze's medium for isolation of actinomycetes.

3. Malt agar (Malt Extract Agar, Biocorp, Poland) for the isolation of mildew fungi.

The TSA plates were incubated for 1 day at $37^{\circ} \mathrm{C}$, then 3 days at $22{ }^{\circ} \mathrm{C}$ and another 3 days at $4{ }^{\circ} \mathrm{C}$. The Gauze's plates were incubated at $28{ }^{\circ} \mathrm{C}$ for 7 days, while MEA plates were incubated 4 days at $30{ }^{\circ} \mathrm{C}$, then 4 days at $22{ }^{\circ} \mathrm{C}$. After the incubation period, quantitative analysis of the grown colonies of microorganisms was performed. On the basis of the microorganism number obtained, the means were calculated from the colony forming units (CFU), separately for each of the groups of microorganisms studied. The number of positive holes for the Mas-100 air 
monitoring system was worked out using a conversion table according to Feller and the obtained colony number was counted over $1 \mathrm{~m}^{3}$ of the atmospheric air.

To determine the dependence between temperature and air humidity and the amount of isolated microorganisms, the Pearson correlation coefficient was calculated.

\section{Results}

The number of microorganisms isolated from atmospheric air at individual research points and the dependence between the number of microorganisms, temperature and air humidity are shown in Tables 1,2 , 3, 4, 5, 6 and 7 and illustrated graphically in Figs. 1, 2, 3,4 and 5 .

The total number of mesophilic bacteria in individual research points varied from 0 to $1360 \mathrm{CFU} \mathrm{m} \mathrm{m}^{-3}$ (Table 1). The largest amount of bacteria was isolated in August at the biological reactor. At the inlet of raw sewage and the outflow of purified wastewater, the largest amount of bacteria was isolated in September $\left(1320 \mathrm{CFU} \mathrm{m}^{-3}\right.$ and $670 \mathrm{CFU} \mathrm{\textrm {m } ^ { - 3 }}$, respectively), and at the control point constituting the background in June (130 CFU m ${ }^{-3}$ ). Mesophilic bacteria were not found in six analysis (at the outflow of purified wastewater: January, February and at the control point: January, February, November, December).

The average number of bacteria in individual research points ranged from 34 to $722 \mathrm{CFU} \mathrm{m}^{-3}$. The highest number of mesophilic bacteria was observed near the biological reactor, the least at the control point (Fig. 1).

$\beta$-hemolytic bacteria were present in 24 out of 48 air samples (Table 2). Their numbers ranged from 0 to $50 \mathrm{CFU} \mathrm{m} \mathrm{m}^{-3}$. The largest amount was found in June at the raw sewage inlet. At this point, they were isolated in five cases. In the place of biological purification, they were present in seven samples up to $45 \mathrm{CFU} \mathrm{\textrm {m } ^ { - 3 }}$ (March). At the outlet of purified wastewater, $\beta$ hemolytic bacteria were isolated in three cases in the amount of 10-15 CFU m ${ }^{-3}$ (June, July, August). These microorganisms were most often present at the control point, in a maximum amount of 25 CFU m ${ }^{-3}$ (June).

During the research, the least $\beta$-hemolytic bacteria were isolated at the third point (purified sewage outlet)—on average $3 \mathrm{CFU} \mathrm{m}{ }^{-3}$, the highest at the second point (biological reactor) $-16 \mathrm{CFU} \mathrm{m}^{-3}$ (Fig. 2).

The amount of $\alpha$-hemolytic bacteria ranged from 0 to $30 \mathrm{CFU} \mathrm{m} \mathrm{m}^{-3}$ (Table 3). They were isolated in 12 samples of the air tested. Most often these microorganisms were present near the raw sewage inlet (point 1). At this point, the largest number (March) was also found. In the place of biological purification, the number of $\alpha$-hemolytic bacteria ranged from 0 to $25 \mathrm{CFU} \mathrm{m}{ }^{-3}$, while in the vicinity of the outflow of purified sewage, it occurred in the amount from 0 to $15 \mathrm{CFU} \mathrm{m} \mathrm{m}^{-3}$. These bacteria were not found at the control point.

The average number of $\alpha$-hemolytic bacteria did not exceed $10 \mathrm{CFU} \mathrm{m}{ }^{-3}$. Most were observed near the raw sewage inlet. At the place of biological purification, an average of $5 \mathrm{CFU} \mathrm{m} \mathrm{m}^{-3}$ occurred, and at the

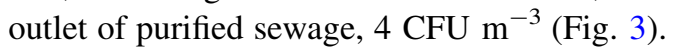

In the studied atmospheric air, actinomycetes occurred in a small amount; they were isolated only in six cases (Table 4). In the largest amount $\left(40 \mathrm{CFU} \mathrm{m} \mathrm{m}^{-3}\right.$ ), they occurred twice in October at the raw sewage inlet and in June at the biological reactor. At the control point, no actinomycetes were observed.

The average concentration of actinomycetes in the

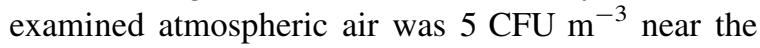
raw sewage inflow, $4 \mathrm{CFU} \mathrm{m} \mathrm{m}^{-3}$ at the biological reactor and $1 \mathrm{CFU} \mathrm{m} \mathrm{m}^{-3}$ in point 3 (Fig. 4).

The number of fungi at individual research points varied widely and ranged from 0 to $1910 \mathrm{CFU} \mathrm{m} \mathrm{m}^{-3}$ (Table 5). Most of mildew fungi were isolated in March near the raw sewage inlet, while in February, they were not observed in the place of biological treatment and near the outflow of purified sewage. At the control point, the most of fungi $\left(810 \mathrm{CFU} \mathrm{m}^{-3}\right.$ ) were observed in July. A high concentration of mildew fungi occurred in summer when the air temperature was the highest. The smallest quantities of these microorganisms were found in January and February, when temperatures were negative and the surface of the earth was covered with snow.

The average number of fungi near the biological reactor, the outflow of purified sewage and at the control point was very similar (Fig. 5). The differences between these points did not exceed $65 \mathrm{CFU} \mathrm{m} \mathrm{m}^{-3}$. The most fungi were found at the raw 
Table 1 Number of mesophilic bacteria in the examined atmospheric air $\left(\mathrm{CFU} \mathrm{m}{ }^{-3}\right)$

\begin{tabular}{|c|c|c|c|c|}
\hline \multirow[t]{2}{*}{ The date of sampling } & \multicolumn{4}{|c|}{ The number of colony forming units (CFU) in $\mathrm{m}^{3}$ of the tested air } \\
\hline & Raw sewage inlet & Aeration chamber & Purified sewage outlet & Control point \\
\hline I 2018 & 260 & 390 & 0 & 0 \\
\hline II 2018 & 180 & 210 & 0 & 0 \\
\hline III 2018 & 380 & 420 & 120 & 10 \\
\hline IV 2018 & 410 & 450 & 160 & 20 \\
\hline V 2018 & 790 & 810 & 210 & 40 \\
\hline VI 2018 & 910 & 1100 & 420 & 130 \\
\hline VII 2018 & 1160 & 1230 & 630 & 80 \\
\hline VIII 2018 & 1030 & 1360 & 490 & 60 \\
\hline IX 2018 & 1320 & 1080 & 670 & 50 \\
\hline X 2018 & 680 & 710 & 220 & 20 \\
\hline XI 2018 & 510 & 560 & 90 & 0 \\
\hline XII 2018 & 310 & 340 & 30 & 0 \\
\hline
\end{tabular}

Table 2 Number of $\beta$-hemolytic bacteria in the examined atmospheric air $\left(\mathrm{CFU} \mathrm{m}{ }^{-3}\right)$

\begin{tabular}{|c|c|c|c|c|}
\hline \multirow[t]{2}{*}{ The date of sampling } & \multicolumn{4}{|c|}{ The number of colony forming units (CFU) in $\mathrm{m}^{3}$ of the tested air } \\
\hline & Raw sewage inlet & Aeration chamber & Purified sewage outlet & Control point \\
\hline I 2018 & 0 & 0 & 0 & 0 \\
\hline II 2018 & 0 & 0 & 0 & 0 \\
\hline III 2018 & 20 & 30 & 0 & 10 \\
\hline IV 2018 & 0 & 35 & 0 & 10 \\
\hline V 2018 & 0 & 20 & 0 & 15 \\
\hline VI 2018 & 50 & 45 & 10 & 25 \\
\hline VII 2018 & 30 & 30 & 15 & 15 \\
\hline VIII 2018 & 15 & 20 & 10 & 20 \\
\hline IX 2018 & 10 & 15 & 0 & 20 \\
\hline X 2018 & 0 & 0 & 0 & 10 \\
\hline XI 2018 & 0 & 0 & 0 & 10 \\
\hline XII 2018 & 0 & 0 & 0 & 0 \\
\hline
\end{tabular}

sewage inlet $\left(573 \mathrm{CFU} \mathrm{m}^{-3}\right)$, and the least at the control point (314 $\mathrm{CFU} \mathrm{m}^{-3}$ ).

After calculating Pearson's linear correlation coefficient, a quite strong dependence was found only between the temperature and the amount of mesophilic bacteria. In relation to $\beta$-hemolytic bacteria and fungi, the dependence between temperature and their amount was moderate, and in the case of $\alpha$-hemolytic bacteria and actinomycetes weak (Table 6).

Humidity of the air did not significantly affect the number of microorganisms studied. The weak dependence was found in relation to the number of mesophilic and $\alpha$-hemolytic bacteria, and in the case of $\beta$-hemolytic bacteria, actinomycetes and fungi, there was no linear dependence between humidity and their abundance (Table 7).

\section{Discussion}

The highest concentration of bioaerosol in the sewage treatment plant is observed near aeration chambers, 
Table 3 Number of $\alpha$-hemolytic bacteria in the examined atmospheric air $\left(\mathrm{CFU} \mathrm{m}{ }^{-3}\right)$

\begin{tabular}{|c|c|c|c|c|}
\hline \multirow[t]{2}{*}{ The date of sampling } & \multicolumn{4}{|c|}{ The number of colony forming units $(\mathrm{CFU})$ in $\mathrm{m}^{3}$ of the tested air } \\
\hline & Raw sewage inlet & Aeration chamber & Purified sewage outlet & Control point \\
\hline I 2018 & 0 & 0 & 0 & 0 \\
\hline II 2018 & 25 & 0 & 10 & 0 \\
\hline III 2018 & 30 & 25 & 10 & 0 \\
\hline IV 2018 & 0 & 0 & 0 & 0 \\
\hline V 2018 & 0 & 20 & 15 & 0 \\
\hline VI 2018 & 25 & 0 & 15 & 0 \\
\hline VII 2018 & 0 & 0 & 0 & 0 \\
\hline VIII 2018 & 0 & 0 & 0 & 0 \\
\hline IX 2018 & 10 & 0 & 0 & 0 \\
\hline X 2018 & 0 & 0 & 0 & 0 \\
\hline XI 2018 & 0 & 10 & 0 & 0 \\
\hline XII 2018 & 25 & 0 & 0 & 0 \\
\hline
\end{tabular}

Table 4 Number of actinomycetes in the examined atmospheric air $\left(\mathrm{CFU} \mathrm{m}{ }^{-3}\right)$

\begin{tabular}{lcccc}
\hline The date of sampling & \multicolumn{2}{c}{ The number of colony forming units $(\mathrm{CFU})$ in $\mathrm{m}^{3}$ of the tested air } \\
\cline { 2 - 5 } & Raw sewage inlet & Aeration chamber & Purified sewage outlet & Control point \\
\hline I 2018 & 0 & 0 & 0 & 0 \\
II 2018 & 0 & 0 & 0 & 0 \\
III 2018 & 15 & 0 & 0 & 0 \\
IV 2018 & 0 & 0 & 0 & 0 \\
V 2018 & 0 & 0 & 0 & 0 \\
VI 2018 & 0 & 40 & 0 & 0 \\
VII 2018 & 0 & 0 & 0 & 0 \\
VIII 2018 & 0 & 0 & 0 & 0 \\
IX 2018 & 10 & 0 & 0 & 0 \\
X 2018 & 40 & 5 & 0 & 0 \\
XI 2018 & 0 & 0 & 0 & 0 \\
XII 2018 & 0 & 0 & & 0 \\
\hline
\end{tabular}

sand catchers, settling tanks and biological deposits (Michałkiewicz et al. 2009; El-Sayed et al. 2015; Kvanli et al. 2008). The formation of a biological aerosol depends on the number of microorganisms in wastewater (Budzińska et al. 2011; Breza-Boruta and Paluszak 2007). Penetration of microorganisms into the air takes place mainly as a result of aeration and mixing of sewage (Hung et al. 2010; Kruczalak and Olańczuk-Neyman 2004; Malakootian et al. 2013). In the studies of Filipkowska et al. (2008) and
Korzeniewska et al. (2008), there were no significant differences in the number of fungi and bacteria depending on the location of research points. However, slightly larger amounts of these microorganisms were found in the sewage treatment plant than outside its borders. In the own studies, the most mesophilic and $\beta$-hemolytic bacteria were observed in the place of biological purification (Tables 1, 2 and Figs. 1,2), and in the case of $\alpha$-hemolytic bacteria, actinomycetes and fungi, near the raw sewage inflow (Tables 3, 4, 5 and 
Table 5 Number of mildew fungi in the examined atmospheric air $\left(\mathrm{CFU} \mathrm{m}{ }^{-3}\right)$

\begin{tabular}{lcccc}
\hline The date of sampling & \multicolumn{4}{c}{ The number of colony forming units $(\mathrm{CFU})$ in $\mathrm{m}^{3}$ of the tested air } \\
\cline { 2 - 5 } & Raw sewage inlet & Aeration chamber & Purified sewage outlet & Control point \\
\hline I 2018 & 80 & 40 & 20 & 30 \\
II 2018 & 70 & 0 & 0 & 220 \\
III 2018 & 1910 & 1010 & 710 & 370 \\
IV 2018 & 110 & 90 & 130 & 480 \\
V 2018 & 620 & 550 & 520 & 480 \\
VI 2018 & 510 & 580 & 840 & 810 \\
VII 2018 & 780 & 510 & 690 & 490 \\
VIII 2018 & 1160 & 490 & 420 & 370 \\
IX 2018 & 730 & 610 & 160 & 170 \\
X 2018 & 470 & 270 & 140 & 210 \\
XI 2018 & 320 & 260 & 70 & 120 \\
XII 2018 & 120 & 90 & & \\
\hline
\end{tabular}

Table 6 Dependence between temperature and the number of microorganisms $\left(\mathrm{CFU} \mathrm{m}{ }^{-3}\right)$ in the examined atmospheric air

\begin{tabular}{|c|c|c|c|c|c|c|}
\hline \multirow[t]{2}{*}{ The date of sampling } & \multirow[t]{2}{*}{ Temperature $\left({ }^{\circ} \mathrm{C}\right)$} & \multicolumn{5}{|c|}{ The number of colony forming units $(\mathrm{CFU})$ in $\mathrm{m}^{3}$ of the tested air } \\
\hline & & Bacteria & $\beta$-hemolytic bacteria & $\alpha$-hemolytic bacteria & Actinomycetes & Fungi \\
\hline I 2018 & -13 & 650 & 0 & 0 & 0 & 230 \\
\hline II 2018 & -19 & 390 & 0 & 35 & 0 & 100 \\
\hline III 2018 & 4 & 930 & 60 & 65 & 15 & 3850 \\
\hline IV 2018 & 12 & 1040 & 45 & 0 & 0 & 700 \\
\hline V 2018 & 21 & 1850 & 35 & 35 & 0 & 260 \\
\hline VI 2018 & 23 & 2560 & 130 & 40 & 55 & 2090 \\
\hline VII 2018 & 28 & 3100 & 90 & 0 & 0 & 2940 \\
\hline VIII 2018 & 32 & 2940 & 65 & 0 & 0 & 2830 \\
\hline IX 2018 & 26 & 3120 & 45 & 10 & 10 & 2130 \\
\hline X 2018 & 18 & 1630 & 10 & 0 & 50 & 1070 \\
\hline XI 2018 & 11 & 1160 & 10 & 10 & 0 & 930 \\
\hline XII 2018 & 6 & 680 & 0 & 25 & 0 & 400 \\
\hline Average & 12.41 & 1670.83 & 40.83 & 18.33 & 10.83 & 1610.83 \\
\hline$r^{*}$ & - & 0.88 & 0.63 & 0.26 & 0.25 & 0.52 \\
\hline
\end{tabular}

* $r$ : Pearson's linear correlation coefficient; < 0.2: no linear dependence; 0.2-0.4: weak dependence; 0.4-0.7: moderate dependence; 0.7-0.9: quite strong dependence; $>0.9$ : very strong dependence

Figs. 3, 4, 5). However, there has been analysis in which larger amounts of microorganisms were found outside the treatment plant. These observations mainly concerned fungi (Table 5).

Breza-Boruta (2012) claims that the concentration of microorganisms in the air depends mainly on temperature. In the research conducted at the municipal waste landfill, the highest number of bacteria was recorded in the spring and summer season, and the fungi in the autumn season. Niazi et al. (2015) in research conducted in the sewage treatment plant in Tehran showed a significant dependence between 
Table 7 Dependence between humidity and the number of microorganisms $\left(\mathrm{CFU} \mathrm{m}{ }^{-3}\right)$ in the examined atmospheric air

\begin{tabular}{|c|c|c|c|c|c|c|}
\hline \multirow[t]{2}{*}{ The date of sampling } & \multirow[t]{2}{*}{ Humidity (\%) } & \multicolumn{5}{|c|}{ The number of colony forming units $(\mathrm{CFU})$ in $\mathrm{m}^{3}$ of the tested air } \\
\hline & & Bacteria & $\beta$-hemolytic bacteria & $\alpha$-hemolytic bacteria & Actinomycetes & Fungi \\
\hline I 2018 & 47 & 650 & 0 & 0 & 0 & 230 \\
\hline II 2018 & 32 & 390 & 0 & 35 & 0 & 100 \\
\hline III 2018 & 44 & 930 & 60 & 65 & 15 & 3850 \\
\hline IV 2018 & 53 & 1040 & 45 & 0 & 0 & 700 \\
\hline V 2018 & 57 & 1850 & 35 & 35 & 0 & 260 \\
\hline VI 2018 & 61 & 2560 & 130 & 40 & 55 & 2090 \\
\hline VII 2018 & 70 & 3100 & 90 & 0 & 0 & 2940 \\
\hline VIII 2018 & 46 & 2940 & 65 & 0 & 0 & 2830 \\
\hline IX 2018 & 67 & 3120 & 45 & 10 & 10 & 2130 \\
\hline X 2018 & 72 & 1630 & 10 & 0 & 50 & 1070 \\
\hline XI 2018 & 76 & 1160 & 10 & 10 & 0 & 930 \\
\hline XII 2018 & 81 & 680 & 0 & 25 & 0 & 400 \\
\hline Average & 58.83 & 1670.83 & 40.83 & 18.33 & 10.83 & 1610.83 \\
\hline$r^{*}$ & - & 0.26 & 0.01 & 0.31 & 0.19 & 0.05 \\
\hline
\end{tabular}

${ }^{*} r$ : Pearson's linear correlation coefficient: $<0.2$ : no linear dependence; $0.2-0.4$ : weak dependence; 0.4-0.7: moderate dependence; 0.7-0.9: quite strong dependence; $>0.9$ : very strong dependence

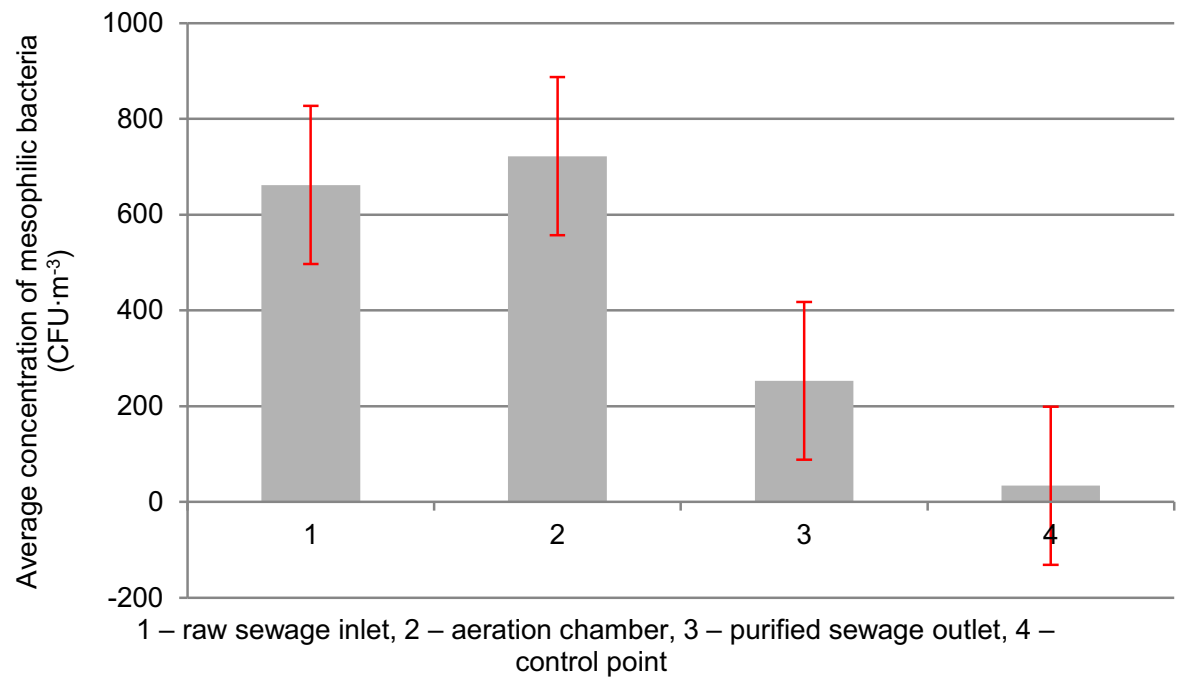

Fig. 1 Average amount of mesophilic bacteria at individual research points

environmental parameters and the concentration of bacteria and fungi in the air. The strongest effect on the occurrence of fungi was humidity, and on the occurrence of bacteria, the air temperature. In the case of bacteria, the effect of wind speed and UV index was also found. In studies by Michałkiewicz et al. (2016), the highest concentration of bacteria and fungi was recorded in the summer, when the temperature was comparable to spring, but the humidity was higher. There were fewer microorganisms in other seasons. Perhaps the reason for the observed differences in the number of microorganisms tested was the different composition of sewage and sludge generated in the treatment process. Korzeniewska et al. (2008) in studies carried out in the area of the hydrophyte sewage treatment plant and in its vicinity also showed 


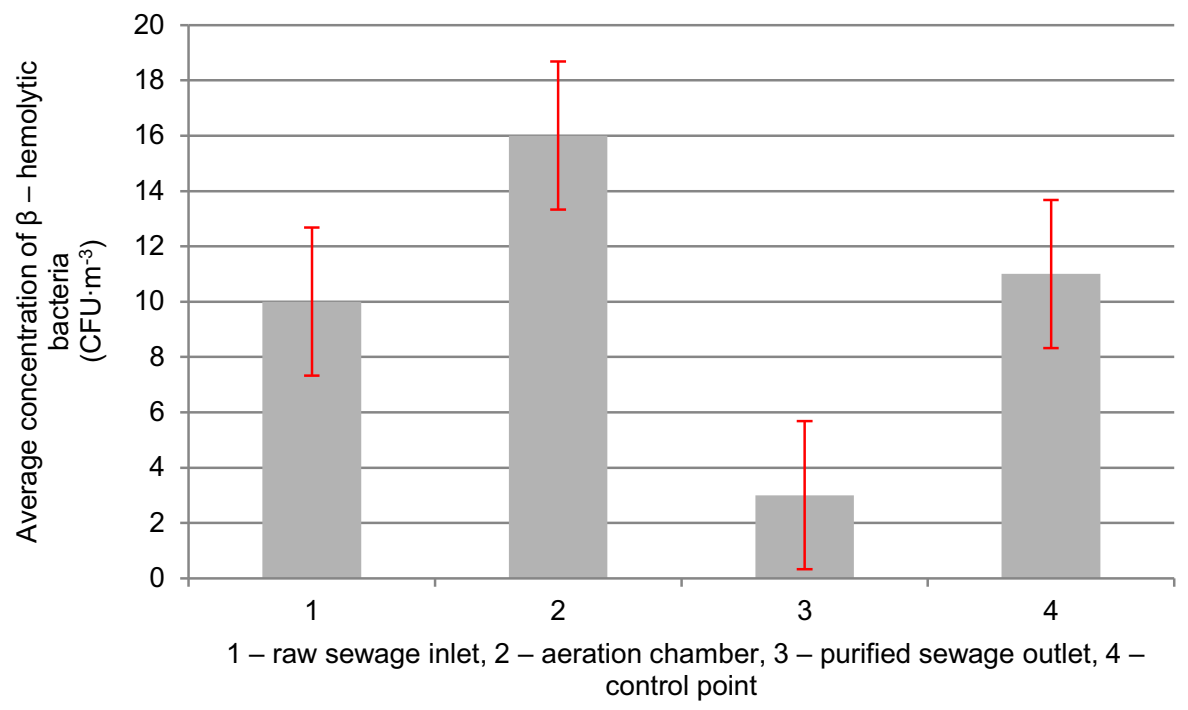

Fig. 2 Average amount of $\beta$-hemolytic bacteria at individual research points

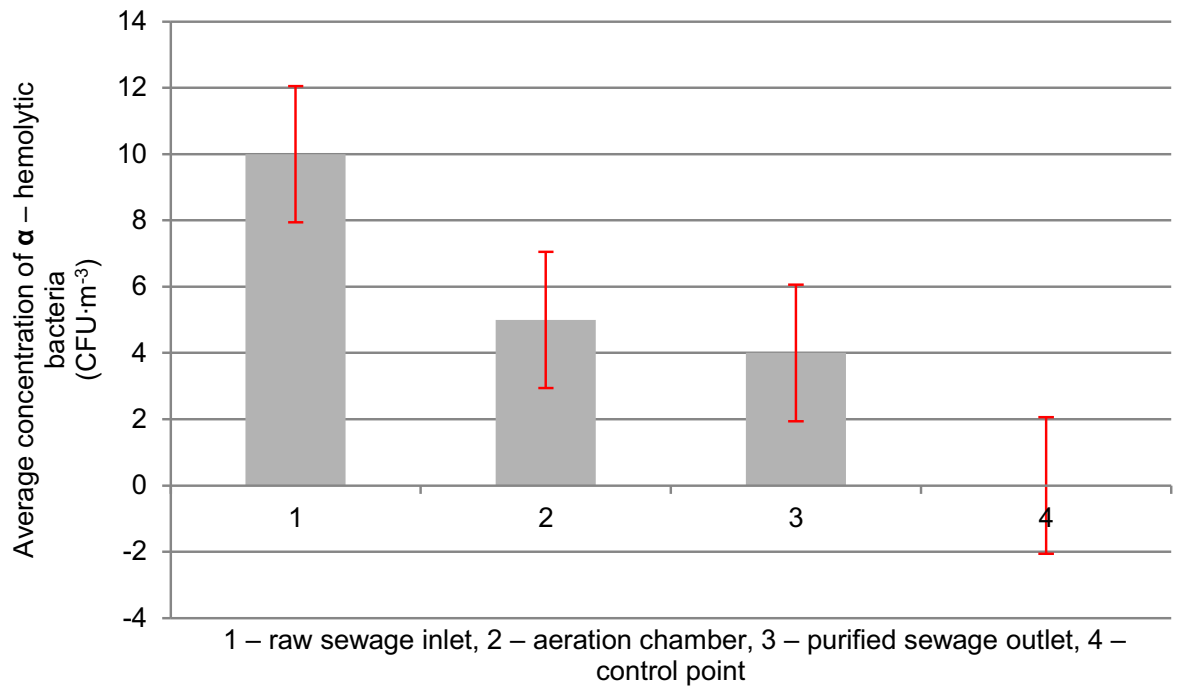

Fig. 3 Average amount of $\alpha$-hemolytic bacteria at individual research points

a dependence between the number of microorganisms in the air and the season of the year. The highest amounts of bacteria were observed in summer, and the lowest in winter. The exception was the most numerous actinomycetes occurring in spring. In own research carried out in the Municipal-Industrial Sewage Treatment Plant in Oświęcim, a quite strong dependence was found only between the air temperature and the amount of mesophilic bacteria (Table 6), the number of which in winter months (DecemberFebruary, temperature from 6 to $-19^{\circ} \mathrm{C}$ ) was definitely less than in other seasons. Of all the microorganisms isolated from air, only $6 \%$ came from analysis carried out in winter, $25 \%$ in autumn, $27 \%$ in spring and as much as $42 \%$ in summer. In contrast, air humidity did not significantly affect the number of microorganisms studied (Table 7), which was confirmed in the literature (Guo et al. 2014; Seetha et al. 2013).

In research conducted by Budzińska et al. (2013), the highest amount of mesophilic bacteria was recorded in the spring and summer period at the sand 


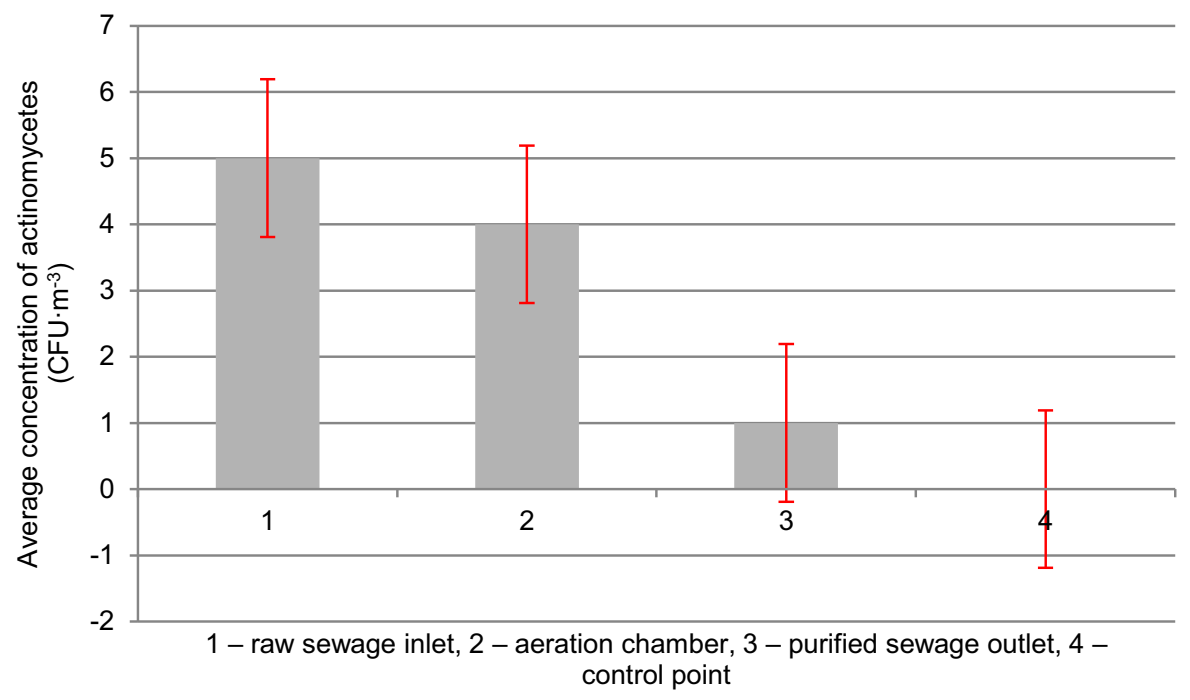

Fig. 4 Average amount of actinomycetes at individual research points

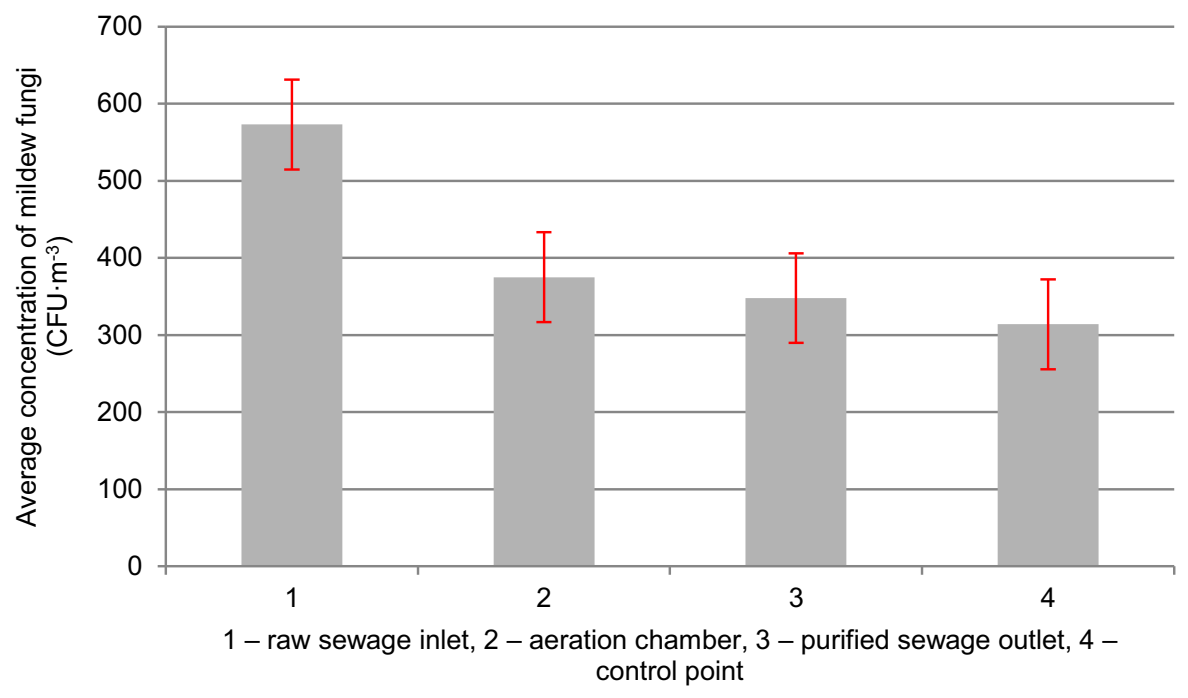

Fig. 5 Average amount of mildew fungi at individual research points

catchers $\left(2020 \mathrm{CFU} \mathrm{m}^{-3}\right)$, and in the autumn-winter period at the SBR reactor $\left(1562 \mathrm{CFU} \mathrm{m}^{-3}\right)$. In the own studies, the most mesophilic bacteria were found in early autumn near the raw sewage inflow (1320 CFU $\mathrm{m}^{-3}$ ), and in late summer at the biological reactor (1360 $\mathrm{CFU} \mathrm{\textrm {m } ^ { - 3 }}$ ), however, their number was slightly lower (Table 1). Large quantities of bacteria, reaching 13,000 CFU m ${ }^{-3}$, were isolated by BrezaBoruta (2010) at the sand catchers in the summer. However, at points located near the aeration chamber, composting plant and outside the sewage treatment plant, the amount of bacteria was much smaller and amounted to a maximum of several hundred $\mathrm{CFU} \mathrm{m}^{-3}$. In other studies, the highest concentration of bacteria was observed near the compost storage site. At this point, from May to October, a strong pollution reaching up to $27,000 \mathrm{CFU} \mathrm{m}^{-3}$ was found. The number of bacteria exceeding $3000 \mathrm{CFU} \mathrm{\textrm {m } ^ { - 3 }}$ was also observed twice at the aeration chambers and twice at a distance of $100 \mathrm{~m}$ from the treatment plant (BrezaBoruta and Paluszak 2007). In the Municipal-Industrial Sewage Treatment Plant in Oświęcim, such high 
amounts of mesophilic bacteria were not found in any of the analysis. The highest number of mesophilic bacteria was isolated at the aeration chamber $\left(1360 \mathrm{CFU} \mathrm{m}^{-3}\right)$, while at the control point, their concentration was maximum $130 \mathrm{CFU} \mathrm{m}^{-3}$ (Table 1).

In research conducted by Wlazło et al. (2002) of the bacteria isolated from the air, about $35 \%$ were Gramnegative bacteria, mainly from the Enterobacteriales order. The most numerous were Enterobacter agglomerans, Acinetobacter calcoaceticus, Pseudomonas putida, Yersinia enterocolitica and Citrobacter freundii. Among the Gram-positive bacteria, the following species were present: Micrococcus, Staphylococcus, Bacillus and Corynebacterium. The $\alpha$-hemolytic bacteria were most often present in air samples collected in the spring months, and $\beta$ hemolytic bacteria in the summer months. The highest concentrations were noted at the raw sewage inlet. In turn, Budzińska et al. (2013) observed an even amount of these organisms throughout the year, most often near sand catchers and settlers. In Breza-Boruta (2010) studies, the number of $\alpha$-hemolytic bacteria ranged from a few to a dozen or so $\mathrm{CFU} \mathrm{m} \mathrm{m}^{-3}$, and $\beta$ hemolytic bacteria to $50 \mathrm{CFU} \mathrm{m}{ }^{-3}$. Most of these bacteria were isolated at the point of mechanical wastewater treatment. Similarly, in own research conducted in the Municipal-Industrial Sewage Treatment Plant in Oświęcim, the number of $\alpha$-hemolytic bacteria was smaller than $\beta$-hemolytic bacteria. The amount of $\alpha$-hemolytic bacteria was up to $30 \mathrm{CFU} \mathrm{m} \mathrm{m}^{-3}$, and $\beta$-hemolytic bacteria up to $50 \mathrm{CFU} \mathrm{m} \mathrm{m}^{-3}$. At the control point, $\alpha$-hemolytic bacteria were not isolated in any of the analysis, while $\beta$ hemolytic bacteria were present in $75 \%$ of analysis. In total, at all research points, $\alpha$-hemolytic bacteria were present in $25 \%$ of the examined air samples, while $\beta$ hemolytic bacteria in 50\% (Tables 2, 3).

Research carried out in many wastewater treatment plants indicates that the most frequent and most frequently occurring actinomyces occur in the composting and sewage sludge storage sites (Breza-Boruta 2010; Budzińska et al. 2011, 2013). In the MunicipalIndustrial Sewage Treatment Plant in Oświęcim, actinomycetes appeared in the air in the smallest quantities (from 0 to $40 \mathrm{CFU} \mathrm{m}^{-3}$ ). They were isolated mainly in summer and autumn. Near the inlet of raw sewage, they were present in three cases, at the biological reactor twice, and at the outlet of purified sewage only once. At the control point, the actinomycetes were not isolated (Table 4). In the studies of Budzińska et al. (2013), the number of actinomycetes was higher. However, in the studies of Breza-Boruta and Paluszak (2007), the concentration of these microorganisms reached even $1040 \mathrm{CFU} \mathrm{m}^{-3}$. Kolwzan et al. (2012) found that actinomycetes isolated from the air came from sources other than the sewage treatment plant, because there were few of them in the sewage. Korzeniewska et al. (2008) report that actinomycetes should not be considered as indicators of pollution when assessing the range of impact of these objects on atmospheric air, because they are constantly found near wastewater treatment plants. This is not confirmed by own studies, in which actinomycetes were isolated in only $13 \%$ of samples, and at the control point outside the wastewater treatment plant, they were not present in any analysis (Table 4).

According to Breza-Boruta (2012), about $70 \%$ of all microorganisms in the air are fungi. This is due to their small requirements in relation to the environment and food, and also involves the production of large amounts of spores. The concentration of fungi in the air in the treatment plant is very often comparable with the background air. Therefore, the assessment of air pollution based on fungi is not reliable because the highest fungus content $\left(4600 \mathrm{CFU} \mathrm{m}^{-3}\right.$ ) was found at the control point located 150 meters from the treatment plant, while the aeration chambers and the compost storage area did not exceed $2000 \mathrm{CFU} \mathrm{m}^{-3}$ (Breza-Boruta 2010). Budzińska et al. (2011) also observed a higher content of fungi outside the treatment plant than near sand catchers or aeration chambers. This did not allow confirmation of the impact of the treatment plant on the content of fungi in the air. In the Municipal-Industrial Sewage Treatment Plant in Oświęcim, fungi constituted almost $50 \%$ of all isolated microorganisms, but their number was varied. Of the 48 research series, in three, the number of fungi at the control point was higher than at the inlet of raw sewage, and in five higher than at the biological reactors (Table 5). Cyprowski et al. (2008) analyzing air samples from four treatment plants showed the highest concentrations of fungi near sewage sludge processing sites (average $770 \mathrm{CFU} \mathrm{m} \mathrm{m}^{-3}$ ), and the lowest in biological treatment sites (average $230 \mathrm{CFU} \mathrm{m}^{-3}$ ). In these studies, there were no significant differences between the concentration of fungi in the treatment plant and in the background. In 
own studies, the highest concentration of fungi was observed near the raw sewage inlet (average $573 \mathrm{CFU} \mathrm{m}^{-3}$ ), and the lowest at the control point

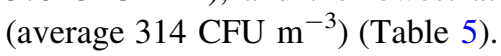

The results of the conducted research show that in the area of the Municipal-Industrial Sewage Treatment Plant in Oświęcim, air pollution occurs with microorganisms, including pathogenic ones. The bioaerosol that arises in this facility may adversely affect human health and the environment. The analysis showed differences in the number and quality of microorganisms depending on the location of the research point, season of the year and air temperature. The obtained results show that the microbial contamination of the air occurs periodically. For this reason, monitoring should be carried out for a longer period of time.

\section{Conclusions}

1. In the area of the Municipal-Industrial Sewage Treatment Plant in Oświęcim, there was a diverse bacterial and fungal microflora.

2. The highest air pollution with microorganisms was observed at the inlet of raw sewage and at the biological reactor.

3. The studies have shown the impact of the season and temperature on the number of microorganisms in the air.

4. In the majority of analysis, the air in the sewage treatment plant was characterized by a higher content of microorganisms than at the control point.

5. The results of the conducted research indicate that air pollution of microorganisms, including pathogens, occurs in the treatment plant.

6. Bioaerosol generated in the Municipal-Industrial Sewage Treatment Plant in Oświęcim may contribute to the deterioration of the quality of atmospheric air and adversely affect human health and the environment.

Acknowledgements This study was funded by the statutory measures of the University of Agriculture-Grant No. 0111000000-D111.

Open Access This article is licensed under a Creative Commons Attribution 4.0 International License, which permits use, sharing, adaptation, distribution and reproduction in any medium or format, as long as you give appropriate credit to the original author(s) and the source, provide a link to the Creative Commons licence, and indicate if changes were made. The images or other third party material in this article are included in the article's Creative Commons licence, unless indicated otherwise in a credit line to the material. If material is not included in the article's Creative Commons licence and your intended use is not permitted by statutory regulation or exceeds the permitted use, you will need to obtain permission directly from the copyright holder. To view a copy of this licence, visit http://creativecommons.org/licenses/by/4.0/.

\section{References}

Adamus-Białek, W., Wawszczak, M., \& Świercz, A. (2015). Impact of sewage treatment plant on local environment. Proceedings of ECOpole, 9(2), 397-404. https://doi.org/ 10.2429/proc.2015.9(2)047.

Ahire, K. D., \& Bhalerao, S. M. (2017). Assessment of occupational health hazards faced by sanitary workers in Kolhapur city. International Journal of Scientific Research, 6(8), 246-247.

Bauer, H., Fuerhacker, M., Zibuschka, F., Schmid, H., \& Puxbaum, H. (2002). Bacteria and fungi in aerosols generated by two different types of wastewater treatment plants. Water Research, 36(16), 3965-3970. https://doi.org/10. 1016/S0043-1354(02)00121-5.

Bawiec, A. J., Pawęska, K., \& Jarząb, A. (2016). Changes in the microbial composition of municipal wastewater treated in biological processes. Journal of Ecological Engineering, 17(3), 41-46. https://doi.org/10.12911/22998993/63316.

Breza-Boruta, B. (2010). An assessment of microbiological air pollution at the sewage treatment plant. Water-Environment-Rural Areas, 10(31), 49-57.

Breza-Boruta, B. (2012). Emission of microorganisms by municipal landfill as a health risk factor. Proceedings of ECOpole, 6(2), 617-623. https://doi.org/10.2429/proc. 2012.6(2)083.

Breza-Boruta, B., \& Paluszak, Z. (2007). Influence of water treatment plant on microbiological composition of air bioaerosol. Polish Journal of Environmental Studies, 16(5), 663-670.

Budzińska, K., Jurek, A., Szejniuk, B., Michalska, M., \& Wroński, G. (2011). Microbiological air pollution in the area of municipal sewage treatment plant. Annual Set The Environment Protection, 13, 1543-1558. (in Polish).

Budzińska, K., Traczykowski, A., Jurek, A., Szejniuk, B., Michalska, M., \& Berleć, K. (2013). Effect of wastewater treatment processes in SBR technology on sanitary condition of atmospheric air. Annual Set The Environment Protection, 15(1), 904-923. (in Polish).

Cyprowski, M., Sowiak, M., Soroka, P. M., Buczyńska, A., Kozajda, A., \& Szadkowska-Stańczyk, I. (2008). Assessment of occupational exposure to fungal aerosols in wastewater treatment plants. Medycyna Pracy, 59(5), 365-371. (in Polish). 
El-Sayed, W. S., Ouf, S. A., \& Mohamed, A. A. (2015). Deterioration to extinction of wastewater bacteria by nonthermal atmospheric pressure air plasma as assessed by 16S rDNA-DGGE fingerprinting. Frontiers in Microbiology, 6(6), 1098. https://doi.org/10.3389/fmicb.2015. 01098.

Filipkowska, Z., Gotkowska-Płachta, A., \& Korzeniewska, E. (2008). Moulds, yeasts and yeast-like fungi in the atmospheric air at constructed wetland systems (whit aerated and stabilization ponds) and in the surrounding area. Water-Environment-Rural Areas, 8(1), 69-82.

Guo, X., Wu, P., Ding, W., Zhang, W., \& Li, L. (2014). Reduction and characterization of bioaerosols in a wastewater treatment station via ventilation. Journal of Environmental Science, 26(8), 1575-1583. https://doi.org/ 10.1016/j.jes.2014.06.001.

Hung, F. H., Kuo, Y. M., Chien, C. C., \& Chen, C. C. (2010). Use of floating balls for reducing bacterial aerosol emissions from aeration in wastewater treatment processes. Journal of Hazardous Materials, 175(30), 866-871. https://doi.org/10.1016/j.jhazmat.2009.10.090.

Kołwzan, B., Jadczyk, P., Pasternak, G., Głuszczak, J., Pawlik, M., Krawczyńska, M., et al. (2012). Assessing air quality in the proximity of a municipal sewage treatment plant: A case study. Environmental Pollution Control, 34(2), 9-14.

Korzeniewska, E. (2011). Emission of bacteria and fungi in the air from wastewater treatment plants: A review. Frontiers in Bioscience (Scholar edition), 3(2), 393-407. https://doi. org/10.2741/s159.

Korzeniewska, E., Filipkowska, Z., Gotkowska-Płachta, A., \& Janczukowicz, W. (2008). Bacteriological pollution of atmospheric air in the constructed wetland (with reed bed system) area and in the surroundings. Water-EnvironmentRural Areas, 8(1), 161-173.

Krajewski, J. A., Cyprowski, M., Szymczak, W., \& Gruchała, J. (2004). Health complaints from workplace exposure to bioaerosols: A questionnaire study in sewage workers. Annals of Agricultural and Environmental Medicine, 11(2), 199-204.

Kruczalak, K., \& Olańczuk-Neyman, K. (2004). Microorganisms in the air over wastewater treatment plants. Polish Journal of Environmental Studies, 13(5), 537-542.

Kvanli, D. M., Marisetty, S., Anderson, T. A., Jackson, W. A., \& Morse, A. N. (2008). Monitoring estrogen compounds in wastewater recycling systems. Water, Air, and Soil Pollution, 188(1), 31-40. https://doi.org/10.1007/s11270-0079498-6.

Lee, M. T., Pruden, A., \& Marr, L. C. (2016). Partitioning of viruses in wastewater systems and potential for aerosolization. Environmental Science \& Technology Letters, 3(5), 210-215. https://doi.org/10.1021/acs.estlett. $6 \mathrm{~b} 00105$.

Li, Y., Yang, L., Meng, Q., Qui, X., \& Feng, Y. (2013). Emission characteristics of microbial aerosols in a municipal sewage treatment plant in Xi'an, China. Aerosol and Air Quality Research, 13, 343-349. https://doi.org/10.4209/ aaqr.2012.05.0123.

Malakootian, M., Radhakrishna, N., Mazandarany, M. P., \& Hossaini, H. (2013). Bacterial-aerosol emission from wastewater treatment plant. Desalination and Water
Treatment, 51(22), 4478-4488. https://doi.org/10.1080/ 19443994.2013.769668.

Michałkiewicz, M., Kruszelnicka, I., Ginter-Kramarczyk, D., \& Mizerna-Nowotna, P. (2016). Odor and microbiological nuisance of the sewage treatment plant: A case study. Ochrona Środowiska, 38(3), 41-48. (in Polish).

Michałkiewicz, M., Pruss, A., Dymaczewsk, Z., Jeż-Walkowiak, J., \& Kwaśna, S. (2011). Microbiological air monitoring around municipal wastewater treatment plants. Polish Journal of Environmental Studies, 20(5), 1243-1250.

Michałkiewicz, M., Pruss, A., Dymaczewski, Z., \& Michalak, J. (2009). Hermetic effect in chosen stages of wastewater treatment on microbiological air pollution. Monographs of the Environmental Engineering Committee, Polish Academy of Sciences, 58(2), 135-143. (in Polish).

Niazi, S., Hassanvand, M. S., Mahvi, A. H., Nabizadeh, R., Alimohammadi, M., Nabavi, S., et al. (2015). Assessment of bioaerosol contamination (bacteria and fungi) in the largest urban wastewater treatment plant in the Middle East. Environmental Science and Pollution Research, 22(20), 16014-16021. https://doi.org/10.1007/s11356015-4793-z.

Nowojewski, A., \& Mniszek, W. (2006). Analysis of workers' occupational exposure to harmful biological agents in a typical municipal sewage treatment plant. Zeszyty Naukowe Wyższej Szkoty Zarzadzania Ochrona Pracy $w$ Katowicach, 1(2), 7-34. (in Polish).

Patil, P., \& Kamble, R. (2017). Occupational health hazards in municipal solid waste collecting workers of Chandrapur city, Central India. International Journal of Environment, 6(1), 46-57. https://doi.org/10.3126/ije.v6i1.16867.

Przybulewska, K., \& Czupryniak, M. (2006). Microbial quality of air in various seasons under the influence of emissions from sewage treatment plant. Environment Protection Engineering, 32(3), 25-30.

Rylander, R. (1999). Health effects among workers in sewage treatment plants. Occupational and Environmental Medicine, 56(5), 354-357.

Sánchez-Monedero, M. A., Aguilar, M. I., Fe-Noll, R., \& Roig, A. (2008). Effect of the aeration system on the levels of airborne microorganisms generated at wastewater treatment plants. Water Research, 42(14), 3739-3744. https:// doi.org/10.1016/j.watres.2008.06.028.

Seetha, N., Bhargava, R., \& Gurjar, B. R. (2013). Gaseous and bioaerosol emissions from municipal wastewater treatment plants. Journal of Environmental Science \& Engineering, 55(4), 517-536.

Thorn, J., \& Kerekes, E. (2001). Health effects among employees in sewage treatment plants: A literature survey. American Journal of Industrial Medicine, 40(2), 170-179. https://doi.org/10.1002/ajim.1085.

Vantarakis, A., Paparrodopoulos, S., Kokki-Nos, P., Vantarakis, G., Fragou, K., \& Detorakis, I. (2016). Impact on the quality of life when living close to a municipal wastewater treatment plant. Journal of Environmental and Public Health. https://doi.org/10.1155/2016/8467023.

Wlazło, A., Pastuszka, J. S., \& Łudzeń-Izbińska, B. (2002). Assessment of workers' exposure to airborne bacteria at a small wastewater treatment plant. Medycyna Pracy, 52(2), 109-111. (in Polish). 